\title{
MANAGING BRANDS’ POPULARITY ON FACEBOOK: POST TIME, CONTENT, AND BRAND COMMUNICATION STRATEGIES
}

\author{
Tri Hanifawati ${ }^{{ }^{*} \text {, }}$ Utan Sahiro Ritonga ${ }^{2}$, and Euis Evi Puspitasari ${ }^{3}$ \\ ${ }^{1,2}$ Department of Agribusiness, Faculty of Science and Technology, University Muhammadiyah \\ Bandung, Bandung, 40614, Indonesia \\ ${ }^{3}$ Department of Communication Science, Faculty of Social and Humaniora, University \\ Muhammadiyah Bandung, Bandung, 40614, Indonesia
}

\begin{tabular}{|c|c|}
\hline ABSTRACT & ARTICLE INFO \\
\hline $\begin{array}{l}\text { Introduction. A brand's popularity on social media affects its customers' } \\
\text { purchasing intention and purchasing decision. Background Problem. A } \\
\text { review of the literature shows that a brand's popularity on social media } \\
\text { has a secure connection with its content and the time information about it } \\
\text { is posted; allegedly the brand's interactions are also influential. Indicators } \\
\text { of its popularity include the number of likes, shares, comments, and } \\
\text { views for it. Novelty. Previous brand popularity studies were limited to } \\
\text { the features of likes, comments, and shares as a function of the content } \\
\text { and time, and OLS was commonly used. However, this study adds the } \\
\text { views feature and the function of the administrator's comments to } \\
\text { complete the gap. GLS is used as the method of analysis. Research } \\
\text { Method. Data are collected through the observation of six top } \\
\text { international food and beverage products' categories on the Facebook fan } \\
\text { page. The data were analyzed using the Seemingly Unrelated Regression } \\
\text { (SUR), and the Mann-Whitney and Kruskal-Wallis methods. Findings. } \\
\text { The study's findings shows that video and the day to post have a } \\
\text { significant influence and increase the number of likes, shares, comments, } \\
\text { and views. A caption only shows significance to increase the number of } \\
\text { likes and shares. The hour has a significant effect on comments and } \\
\text { shares. The time of posting indicates that posting on weekdays and during } \\
\text { busy periods is more effective for increasing the popularity of brands. } \\
\text { The administrator's comments significantly influence the increase in the } \\
\text { number of comments and views, while two-way communication is more } \\
\text { significant for increasing a brand's popularity. Conclusion. These } \\
\text { findings provide a deeper insight to help managers to improve their } \\
\text { brand's popularity on social media by exploring how brands manage their } \\
\text { fan pages. }\end{array}$ & $\begin{array}{l}\text { Article history: } \\
\text { Received 13 May } 2019 \\
\text { Received in revised form } \\
\text { 26 Juny } 2019 \\
\text { Received in revised form } \\
26 \text { August } 2019 \\
\text { Accepted } 1 \text { September } \\
2019 \\
\text { Keywords: } \\
\text { brand popularity, } \\
\text { brand communication, } \\
\text { branding strategy, } \\
\text { social media marketing, } \\
\text { online marketing } \\
\text { JEL Code: } \\
\text { M15, M31, M37 }\end{array}$ \\
\hline
\end{tabular}

\footnotetext{
* Corresponding author at the Department of Agribusiness, Faculty of Science and Technology, University Muhammadiyah Bandung, Jalan Soekarno Hatta No. 752, Cipadung Kidul, Panyileukan, Bandung, 40614, Indonesia.

E-mail address: trihanifawati@gmail.com (author\#1), utanritonga@gmail.com (author\#2), tukdewipuspita@gmail.com (author\#3)
} 


\section{INTRODUCTION}

Social media is a system of highly interactive platforms that allow individual users and communities to share, co-create, discuss, and modify user-generated content (Piller, Vossen, \& Ihl, 2012; Muninger, Hammedi \& Mahr, 2019). The platforms represent sources of data and business intelligence, in the form of customer feedback and market insights that can inform stages of the innovation process (Roberts \& Candi, 2014; Muninger et al., 2019). Social media is a new form of engagement, with many opportunities for brands to extract value from their existing and potential consumers. On these platforms, a brand can receive suggestions and feedback more quickly from its consumers, enhance special offers, allow people to respond, handle problems and provide a better service to its consumers (Hausman, Kabadayi \& Price, 2014).

The We Are Social (2019) reported that the number of active social media users worldwide is $45 \%$ of the total population. The United States has the highest number of users $(66 \%)$, then Europe (55\%), the Middle East (53\%), while Indonesia has $56 \%$. These numbers are based on the monthly active users, their user accounts, and unique visitors to each platform compared to the total population in each country. The average daily time spent using social media via any device worldwide is 2 hours 16 minutes, but the countries with the longest time per day are the Philippines (4 h $12 \mathrm{~m})$, Brazil (3 h $34 \mathrm{~m}$ ), Columbia ( 3 h $31 \mathrm{~m}$ ), Indonesia ( $3 \mathrm{~h} 26 \mathrm{~m}$ ) and Thailand $(3 \mathrm{~h} 11 \mathrm{~m})$. Referring to the Statista (2018), the number of social media users is increasing significantly every year. The top five most used social media systems worldwide are Facebook (15.99\%), YouTube (13.38\%), Whatsapp (10.56\%), FB Messenger (9.15\%), and Wechat (7.62\%) (We Are Social, 2019). While in Indonesia they are Facebook (41.84\%),
Twitter (26.92\%), YouTube (11.66\%), Instagram (9.99\%), and Pinterest (8.43\%) (Statcounter, 2019).

Facebook is the platform with the most significant users; its platform has collaboration and sharing features (Erdoğmuş \& Çiçek, 2012). With these, users can actively share opinions, experiences, and gather information about a brand (Kim \& Johnson, 2016). Previous research reported that many food companies have successfully built their brands through social media (Vukasovič, 2013). These companies usually used a Facebook fan page to promote their brands. On this page, the brands communicate directly with their existing and potential customers, display information about new products, and increase new customer who interest in the product (Wang, Pauleen \& Zhang, 2016).

The most important part of Facebook is its ability to build an electronic word of mouth system, which is a chain message utilizing various features such as posts, shares, and comments. These features make access to the brand faster (Vukasovič, 2013; Kim \& Johnson, 2016); give quicker access to information about the product (Verhoef \& Lemon, 2013) and communication with the customers is improved (Sabate et al., 2014; Wang et al., 2015). This platform also has the benefit of increasing brand awareness in the specific target market, presenting the target audience with information about the offered product, encouraging healthy market competition and maintaining its customers' loyalty (Jothi, Neelamalar, \& Prasad, 2011). The benefit for the customers is they can share information or experiences, learn, interact, buy, and even evaluate the brand (Hudson, Huang, Roth \& Madden, 2016).

Why does a company popularize its brand? The brand's name has a significant effect on its consumers' perceptions, alternative selections, 
and behavior after purchase (Hanifawati, Suryantini \& Mulyo, 2017). A brand's posting popularity relates to its actual consumer sales, purchase intentions, and stock price (Lin, Swarna, \& Bruning, 2017). Other research found that brand popularity effects the purchase decision (Magnini, et al., 2013; Saboo, et al., 2016; Lin et al. 2017; Kim, 2018; Kudeshia \& Kumar, 2017). So, likes, shares, and comments can be useful proxies for a brand's posting popularity on social media (Sabate et al., 2014; Swani et al., 2017; Lin et al., 2017).

Zadeh \& Sharda (2014) suggested that the popularity of brands is a probability function of time and the number of followers. Sabate et al. (2014) found that a brand's posting popularity is a function of the number of followers, the number of text characters used, image, video, and the hour to post on social media. Their study was limited to only a likes and comments model. Sabate et al. (2014) explain that image and the number of followers have a significant relationship with likes and comments; the number of text characters used and the video have a significant effect only on likes; while the hour and url links are significant only for comments. They also explained that posts made during business hours get more comments than those made outside normal working hours. So, we conclude that the content and time of a post have a connection with the number of likes, comments, shares, and views. In some reports, we found that these functions have significant effects but in others they were not significant.

This research's aim is to understand the effects of these functions on the popularity of a brand's posts on Facebook with completing the gap. There are two gaps completed in this study, namely variable of views and brand communication. Previous studies did not provide information about the views model and the effects of brand communication on models of the brand's popularity. Just having followers liking or commenting on posts are not enough to increase the number of potential customer or to reach a targeted audience. A video needs views, the greater the number of views, the greater is the possibility of reaching the target audience; while an understanding of the brand's communications helps it to become more deeply engaged with its customers. These are the reasons why completing the gap in this study is essential.

This research has two objectives. First, to determine the effects of the content (video, image, caption), time of posting (day, hour) and brand communication (in the form comments by an administrator) on the number of likes, shares, fans' comments, and views. Second, to show the most effective time and form of brand communication to increase the popularity of the brand's posts. Previous research and the current literature have shown that these models assisted in mapping the pattern of human interactions on social media (Sabate et al., 2014; Kaur et al., 2019). Knowing the significant factors may create a better understanding of the changing mode of human interactions, and thus help companies to become more engaged with their customers.

Following this introduction, the next section presents the literature review and hypotheses. Section 3 describes the method, data, and analysis chosen. Section 4 explains the results of the hypotheses and has the discussion. In section 4, we present the findings and develop models of the likes, comments, shares, and views related to hours, days, videos, images, captions, and administrators' comments. Finally, we present the implications for managers, any limitations, and suggestions for future research.

\section{LITERATURE REVIEW}

There are two forms of interaction on Facebook: active interaction such as liking, sharing, 
commenting, reacting, and passive interaction such as clicking, watching, or viewing ( $\mathrm{Su}$, Reynolds \& Sun, 2015), (Kaur et al., 2019). In 2016, Facebook released a new reaction feature that consists of five pre-defined emotions, namely "love," "wow," "sad," "angry" and "haha" that permit users to articulate their feelings wordlessly (Smieško, 2016; Kaur et al., 2019). This research limited itself to the features of likes, shares, fans comments, and views. Views is included because the majority of the content posted in this research is on video, and this feature only relates to video.

\section{The content, time, brand communication and brand popularity}

Mood and timing were found to significantly influence the users' behavior during their social media engagements (Hellberg, 2015). The timing of the post and the number of followers influence the brand's popularity (Zadeh \& Sharda, 2014). Previous research found that the timing and content of a post, and the number of followers effects the number of likes and comments (Sabate et al., 2014; Schultz, 2017). The number of fans and the timing of the post increase the number of likes and comments (Swani et al., 2017).

Clicking the like button implied that a user agrees with the content and wants to express his/her preference to friends, this button is used as a tool to provide positive feedback on things they like (Kaur et al., 2019). For comments, shares, and reactions, users are more likely to hit any one of the buttons if they agree with the content that has a read-only attribute (Kaur et al., 2019). Users prefer videos and images, rather than text messages (Brookes, 2010), so images and videos are more useful for increasing a brand's popularity than text messages. Visual content is the most effective for increasing the number of followers and likes. Studies have found that visual content has a positive effect on purchasing decisions (Sharma, Bhosle, \& Chaudhary, 2012; Hellberg, 2015; Gulamali \& Persson, 2017).

Content that contains expressions of humor, questions something, awards something, and provides information on discounts all affect the number of likes (Su et al., 2018). Sabate et al. (2014) found that the number of characters used in a text, links to other things, videos, time, and day to post have a positive linear correlation to likes, while pictures and post time only affect the comments. Schultz (2017) found that likes is significantly affected by pictures, a hashtag, calls to act, contests, and voting, but content categories which include references to charity, competitions, human resources, and promotions have an adverse effect on likes. Time and the number of followers also positively enhance the number of likes. He explained that a post's vividness (pictures, events, and videos) showed a significant effect on likes and shares but an adverse effect on comments. Some suggested that links in posts may decrease the number of comments (Sabate et al., 2014) but others tend to suggest that the fans of brand pages prefer interactivity, as long as it is not overly timeconsuming (Lin et al., 2017). The use of corporate brand names, product brand names, an information search, links, and direct calls to purchase by a post reduce the number of likes and comments (Swani et al., 2017).

An increasing number of shares indicates that users think a post should be seen by other users, therefore, increasing its influence and visibility (Coursaris, Van Osch \& Balogh, 2016; Kim \& Yang, 2017; Kaur et al., 2019). Likes and shares are generally related. If the user agrees, he likes the content; then if he thinks that the information is essential, and should be known by others, the post will be shared. Su et al. (2018) reported that the contents of a post (image, 
video, link, caption) that communicate a brand's image or story are more likely to be shared and have a positive effect on the number of shares, while posts dealing with environment concerns or charity have an adverse effect on the shares. Schultz (2017) found that all the vivid characteristics, interactive links, charity information, competitions, and human resources have an adverse effect on shares. The content that contains information about a contest, voting, holidays, and promotions, as well as time at the top of the page and the number of fans, all have significant and positive effects on the number of shares. Promotions create a negative effect on the number of likes, but they have a positive effect on the number of shares. He stated that although promotional content does not improve the number of likes, it is effective when used to inform about sales and discounts.

Another form of communication on Facebook, besides posting content, is interacting directly with fans via the comments feature. This feature allows a brand to actively communicate with its fans. There are two forms of marketing communication: inbound and outbound marketing. Referring to Kallio (2015), outbound marketing is known as traditional marketing; the most frequently used tools are magazines, TV, newspapers, radio broadcasts, direct mail letters, and exhibitions, while inbound marketing is based on a two-way communication between the marketer and the customer. Inbound marketing aims to gain a customer's interest and trust in a brand, without purchasing it. With inbound marketing, a brand has a chance to build a stronger connection and escalate awareness of the brand among its customers. Social media is a useful tool for inbound marketing.

On Facebook, a brand builds an interactive communication with its fans using the comment feature. Schnotz (2005) suggested that a brand which is represented by an administrator should be humble, attractive, honest, and active. Humans show different learning patterns in their long-term memory and sensory modalities (e.g., touch, visual, pain, hearing) to captions and spoken information. In the human brain, spoken messages and captions are processed in the verbal channel, pictures in the pictorial channel, while video is in both the verbal and pictorial channels. Then, he also explained that an audience might react differently to different media and communication characteristics. This indicates that an administrator must have interpersonal communication skills, and be friendly and professional.

Customers like to interact with brands, ask questions, and exchange their opinions via social networking sites. Thus, the degree of interactivity of a post is another critical characteristic of a brand's compelling posts. A post's interactivity can be improved through the use of question and answer dialogues, promotions, and contests, links to other websites, votes, or other characteristics that require some form of consumer action (Lin et al., 2017). Research suggests that brand interaction is related to a brand's ability to attract likes and comments or other forms of engagement (Sabate et al., 2014; Schultz, 2017; Kaur et al., 2019). To survive, a brand has to come up with more innovative, interactive and exciting kinds of interaction, which makes its fans access and develop a closeness with the different communication strategies of a brand, and with its name and the services it offers (Vukasović \& Strašek, 2014).

This study follows a similar approach to that of Sabate et al. (2014), who used Facebook and the travel products' category as an observation sample. This paper develops the study by Sabate et al. (2014) in several aspects. First, they studied the likes and comments model, while this study analyzes four models, namely likes, fans comments, shares, and views. Second, the 
independent variables measured by them were an image, a video, the number of characters in a text, days to post, and hours to post; while this study added administrators' comments and captions as new variables. Third, they used the OLS model to analyze two models' equations, while this study used GLS to analyze four models' equations, as the previous research found that GLS overcomes residual errors better than OLS for equations with more than one dependent variable.
Figure 1 represents the research framework and hypotheses of this study. There are four dependent variables, namely likes, fans comments, shares, and views, and six independent variables, namely hour, day, video, image, caption, and administrators' comments. It proposes that these six independent variables have significant effects on the four dependent variables.

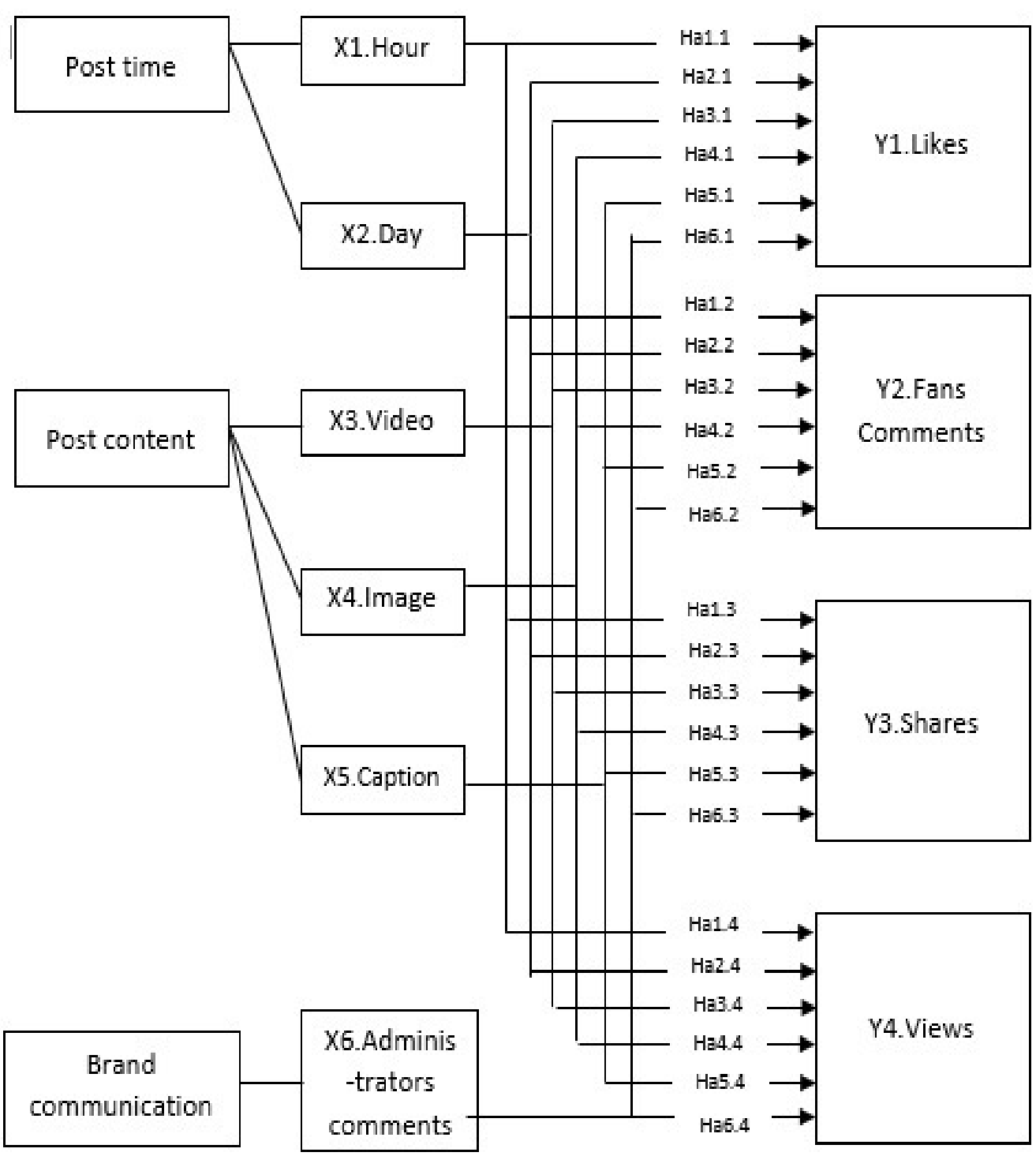

Notes: $\longrightarrow=\mathrm{X}$ has significant effects on $\mathrm{Y}$

Source: Authors, 2019

Figure 1. Research framework and hypotheses 


\section{The effectiveness of the time of the post and the brand's communication}

Previous research found that there were different effects of the time of the post and the different types of content in a post on the brand's popularity. Based on the time, Brookes (2010), suggested that posting on a Friday is $64 \%$ more effective than on a Sunday and $13 \%$ more effective than on a Saturday. However a post on Friday is only $7 \%$ more effective than one on a Monday and 3\% more effective than on Tuesday and Wednesday. Based on the time of posting, posts before noon (00:00-12:00) are 65\% more effective than those done after midday (12:0123:59 at night). Buddy Media Inc. (2012) and Sabate et al. (2014), also reported that posts during "busy hours" (08:00-18:00) are more effective than posts made in "non-busy hours" (18:01-07:59). Refers to Sabate et al. (2014), that working hours for Friday occur at 8:00 15:00.

The effectiveness of posting during the day is still debatable, the effectiveness being measured by fans involvement in the form of their likes, shares, and comments. Sabate et al. (2014) found no effects of either the date or the day on the number of likes and comments, while Cvijikj \& Michahelles (2013) found significant effects on comments but not for likes. Then, Buddy Media Inc. (2012) reported that posting on the weekend is more effective than on weekdays, but Brookes (2010) reported that weekdays are more effective. Schultz (2017) also found that posting on weekdays does not affect the posted brand's interactions. Thus, examining the influence of the day on a brand's popularity is still important, to provide more insight.

Brand communication influences customers to think and emotional feeling to the brand (Hudson et al., 2016). Through their comments, consumers can share their experiences, evaluate, offer suggestions, or giving feedback about the brand. There are two forms of brand communication: passive and active communication. Passive communication is when the brand's administrator posts something, but does not provide any feedback to the fans' comments. Whereas active communication is when the administrator not only posts, but also gives feedback in the form of replies to the comments. The communication theory states that building a two-way communication is more useful for building lasting relationships. Of course, people feel more comfortable with a brand when the brand actively responds to their comments. However, we more often find brands that are not responsive to their consumers' comments.

Therefore, the hypotheses for this study are as follows:

$\mathrm{Hb}_{1}$ : There is a difference in their effect between posts on weekends and weekdays

$\mathrm{Hb}_{2}$ : There is a difference in their effect between posts during "busy and nonbusy" hours

$\mathrm{Hb}_{3}$ : There is a difference in their effect between active and passive brand communications

\section{THE METHOD, DATA, AND ANALYSIS}

A quantitative method was used to examine the relationships between the variables based on the statistical analysis. Primary data were collected through observation of the activities of the top six international food and beverage product categories from March 13 to April 13, 2018 on their Facebook fan pages. Their followers come from all over the world (an international audience). Facebook was chosen because it has the largest number of users. The criteria for the top brand's are those with the largest number of followers in March 2018, referring to https://fan pagelist.com/, namely Nutella, Red Bull, 
Starbucks Coffee, Nescafe, Monster Energy, and Coca Cola. This information can be found by visiting the site, going to the brand's menu on the top page then clicking on food/beverage. The brands' rankings on the site may change every time. Referring to Sabate et al. (2014), we have modified the definition and measurement of the variables and presented this in Table 1.

Validity and reliability testing was conducted using Pearson's correlation method (Kuncoro, 2013) using SPSS 22. The hypotheses (Fig. 1) were tested with Seemingly Unrelated
Regression (SUR) using EViews 10. This test aims to determine the effects of the independent variables on the dependent variables. The dependent variables are the number of likes (Y1), shares (Y2), fans comments (Y3), and views (Y4). While the independent variables are the hour (X1), day (X2), video (X3), image (X4), caption (X5), and administrators' comments (X6). Referring to Henningsen \& Hamann (2007), Beasley (2008) and Fitrianti (2018), the equation for SUR is shown in Equation 1:

Table 1. Measurement and definition of the dependent and independent variables

\begin{tabular}{|c|c|c|}
\hline Variables & Definition & Measurement \\
\hline Likes & The number of likes on a post & $\begin{array}{l}\text { Numeric/amount } \\
0: \text { "no likes." } \\
\text { 1: "one or more likes." }\end{array}$ \\
\hline Fans comments & The number of comments on a post & $\begin{array}{l}0: \text { "no comment" } \\
\text { 1: "one or more comments" }\end{array}$ \\
\hline Shares & The number of shares on a post & $\begin{array}{l}\text { Numeric/amount } \\
0: \text { "no shares." } \\
1: " \text { one or more shares." }\end{array}$ \\
\hline Views & The number of views on a post & $\begin{array}{l}\text { Numeric/amount } \\
0: \text { "no views." } \\
\text { 1: "one or more views." }\end{array}$ \\
\hline Video & The number of videos posted in a day & $\begin{array}{l}\text { Numeric } \\
0: \text { "no post." } \\
\text { 1: "one or more posts." }\end{array}$ \\
\hline Image & The number of pictures posted in a day & $\begin{array}{l}\text { Numeric } \\
0: \text { :"no post." } \\
\text { 1: "one or more posts." }\end{array}$ \\
\hline Caption & $\begin{array}{l}\text { A text message included in a post } \\
\text { image/video (include link or URL) }\end{array}$ & $\begin{array}{l}0: \text { "no caption." } \\
1: \text { "with the caption." }\end{array}$ \\
\hline Hour & Hours when content posted & $\begin{array}{l}\text { Numeric } \\
\text { 0: "no post." } \\
\text { 1:"non-busy hours" (00:00-7:59 and 18.00- } \\
\text { 23:59 on Monday to Friday; all day Saturday } \\
\text { and Sunday) } \\
\text { 2: "busy hours" (08:00-18:00 on Monday to } \\
\text { Thursday and 08:00-15:00 on Friday) }\end{array}$ \\
\hline Day & The date day when content posted & $\begin{array}{l}\text { Name of day } \\
\text { 0: "no post." } \\
\text { 1: "post on weekends" (Friday at 15:00 to } \\
\text { Sunday at 24:00) } \\
\text { 2: "post on weekdays" (Monday to Thursday) }\end{array}$ \\
\hline $\begin{array}{l}\text { Administrators' } \\
\text { comments }\end{array}$ & $\begin{array}{l}\text { The number of administrators' } \\
\text { comments in a post }\end{array}$ & $\begin{array}{l}0: \text { "no comments." } \\
\text { 1:"one or more comments." }\end{array}$ \\
\hline
\end{tabular}

Source: Authors (2017) modified from Sabate et al. (2014) 


$$
\mathrm{Y}_{\mathrm{i}}=\mathrm{X}_{\mathrm{i}} \beta_{\mathrm{i}}+\varepsilon_{\mathrm{i}} \quad \mathrm{i}=1,2, \ldots
$$

where $\mathrm{Yi}$ is a dependent variable, $\mathrm{Xi}$ is a matrix of independent variables, $i$ is the number of independent variables, $\beta \mathrm{i}$ is a vector coefficient, and $\varepsilon i$ is a residual.

In a model equation with more than one dependent variable, where a related residual effect is produced, the SUR method is considered to be capable of reducing any residual correlation problems in the system (Greene, 2002). SUR is a Generalized Least Square (GLS) method; previous research has found that this method overcomes residual errors better than the Ordinary Least Square (OLS) does (Widyaningsih, et al 2014). Tests of assumptions are variance-covariance matrix correlations, heteroscedasticity, and autocorrelations. The assumption test included whether there was an error correlation in the model; at least one error in the equation is considered to be heteroscedastic, and the disturbance variable is a nonautocorrelation (Greene, 2002; Fitrianti, 2018). Hypotheses $\mathrm{Hb}_{1}, \mathrm{Hb}_{2}$, and $\mathrm{Hb}_{3}$ were measured using the Mann-Whitney and Kruskal-Wallis methods. Mann-Whitney is used to analyze differences in two categories of comments by an administrator, while Kruskal-Wallis is for three categories of the hour and day (Table 1).

\section{RESULTS}

\section{Validity and reliability of the model}

A validity test is performed using predictive validity, with reference to Mohajan (2017). He suggested that this test suits applied research. A higher correlation between the criterion and the predictor indicates that the predictive validity is greater. According to Taherdoost (2016), the minimum recommended value for the valid items' loading is above 0.4, but Mohajan (2017) said that items with a loading between 3.0 and 0.6 are accepted as valid items. The decision about validity in this study refers to Mohajan (2017). The results indicate that an item of variable of image is not-valid with a correlation value of $-0.154(<0.3)$, while other items are valid with correlation values of between $0.3-$ 0.8. According to Taherdoost (2016), the items with a loading below 0.3 is not valid and deleted for further analysis.

The most frequently used reliability test is Cronbach's alpha coefficient (Mohajan, 2017), (Taherdoost, 2016). Cronbach's alpha values above 0.70 are acceptable and satisfactory, above 0.80 are quite good, above 0.90 reflect exceptional consistency (Mohajan, 2017). This is almost in line with Taherdoost (2016). In social studies, an acceptable range for alpha is from 0.70 to 0.80 (Mohajan, 2017). Thus, we concluded that the reliability in this study is acceptable with the Cronbach's alpha of the model being 0.869 .

\section{Heteroscedastic test results}

Unlike the OLS regression test, which requires all the errors to be homogeneous (homoscedastic), the SUR model would recognize at least one heteroscedastic equation (Fitrianti, 2018). The error value in the likes model ( $\mathrm{p}$-value $<0.05$ ) is heteroscedastic, whereas the fans comments, shares, and views are homoscedastic ( $\mathrm{p}$-value $>$ 0.05 ). Thus the assumption of heteroscedasticity for the SUR analysis was fulfilled.

\section{Autocorrelation test results}

The detection of autocorrelation was done using the Durbin-Watson method. Autocorrelation occurs if the Durbin-Watson value is $<1.5$ or $>2.5$ (Widarjono, 2010). Durbin-Watson values are $1.889831(>1.5)$ for likes; $1.827462(>1.5)$ for fans comments; $2.153445(<2.5)$ for shares and $2.459231(<2.5)$ for views. Thus, the nonautocorrelation assumptions for the SUR test are fulfilled. 


\section{Variance-covariance matrix correlation test results}

A variance-covariance matrix correlation test was conducted to determine the error correlation in the equation's system (Greene, 2002), to ensure that SUR is the right approach for this study. An equation model has a correlation error if the $\mathrm{p}$-value $<0.05$. The results show that there is an error correlation in the equation's system with a significance value ( $\mathrm{p}$-value $=0.000)<$ 0.05 . Thus, the SUR is a feasible method to use in this study.

\section{Individual variables' test results and modeling equation}

Our question is how to maximize the role of social media to reach the targeted market more widely. This result provides some answers about how a business can maximize the function of social media branding. By knowing the factors which influence the popularity of the brand, social media branding activities will be more effective. The results of the individual variables' test are shown in Table 2.

\section{Model of Likes}

Based on Table 2 and Equation 2, we found that the day ( $\mathrm{p}$-value $<0.001 ; \beta=+0.254$ ) and video ( $\mathrm{p}$-value $<0.001 ; \beta=+0.462$ ) have significant positive effects on likes, caption (p-value 0.0471 $<0.05 ; \beta=-0.078$ ) shows a significant negative effect on likes. The explained variance $\left(\mathrm{R}^{2}\right)$ in the likes model is $64.17 \%$ referring to the adjusted R-squared value of 0.641660 . To find the coefficient of determination in an equation with more than one independent variable, an adjusted R-square is used (Mansuri, 2016). While on the other hand, the hour of the post has no significant negative effect, and administrators' comments have no significant positive effects on the number of likes. The equation for the likes model is shown in Equation 2. The number of equations is rounded to three decimal places.

$$
\begin{aligned}
\text { LIKES }= & 0.238-0.039 * \text { HOUR }+ \\
& 0.254 * \mathrm{DAY}+0.462 * \mathrm{VIDEO}- \\
& 0.078 * \mathrm{CAPTION}+ \\
& 0.0338 * \mathrm{~A} \_ \text {COMMENT }+\varepsilon
\end{aligned}
$$

Mansuri (2016) explained that the positive and negative signs indicate the direction of the relationship between the independent and dependent variables. Positive $(+)$ means an influence in one direction; increasing the independent variable will increase the dependent variable; while negative (-) indicates the opposite effect, increasing the independent variable will decrease the dependent variable. However, he said that this interpretation does not apply to variables using a Likert scale. Equation 2 indicates that increasing the number of videos will increase the number of likes; increasing the number of days will also increase the number of likes. This finding supports the study by Sabate's et al. (2014), there are significant and positive effects between likes and videos, but it is contrary to Schultz (2017) and Swani \& Milne (2017), who found no significant effects. The caption in this study has adverse effects; increasing the number of captions reduce the number of likes.

\section{Model of Fans Comments}

The fans comments model, in Table 2, shows that the hour ( $\mathrm{p}$-value $<0.05 ; \beta=-0.076$ ) significantly and negatively effects fans comments, while the day ( $\mathrm{p}$-value $<0.001 ; \beta=$ +0.182 ), video ( $\mathrm{p}$-value $<0.001 ; \beta=+0.541$ ) and administrators' comments ( $\mathrm{p}$-value $<0.05 ; \beta=$ +0.0876 ) all have a significant and positive effect by increasing the number of fans comments. The fans comments model explains $54.53 \%\left(\mathrm{R}^{2}\right)$ of the comments' variance, with an adjusted R-squared of 0.545342 . The caption shows no significant negative effect on fans comments. 
Table 2. Summary of individual variable test results

\begin{tabular}{llllrlr}
\hline $\begin{array}{c}\text { Dependent } \\
\text { Variables }\end{array}$ & \multicolumn{1}{c}{$\begin{array}{c}\text { Independent } \\
\text { Variables }\end{array}$} & Coefficient & Prob. & $\begin{array}{c}\text { Adjusted R- } \\
\text { Squared }\end{array}$ & $\begin{array}{c}\text { Hypo- } \\
\text { theses }\end{array}$ & $\begin{array}{c}\text { Hypotheses } \\
\text { Results }\end{array}$ \\
\hline Likes & Constant & 0.238395 & 0.0000 & 0.641660 & & \\
& Hour & -0.038646 & 0.1363 & & Ha1.1 & Not supported \\
& Day & 0.254234 & $0.0000^{* * *}$ & & Ha2.1 & Supported \\
& Video & 0.461783 & $0.0000^{* * *}$ & & Ha3.1 & Supported \\
& Caption & -0.077830 & $0.0471^{* *}$ & & Ha5.1 & Supported \\
& Administrator's comment & 0.033823 & 0.2827 & & Ha6.1 & Not supported \\
Fans comments & Constant & 0.211823 & 0.0000 & 0.545342 & & \\
& Hour & -0.075696 & $0.0162^{* *}$ & & Ha1.2 & Supported \\
& Day & 0.181785 & $0.0000^{* * *}$ & & Ha2.2 & Supported \\
& Video & 0.541315 & $0.0000^{* * *}$ & & Ha3.2 & Supported \\
& Caption & -0.022389 & 0.6375 & & Ha5.2 & Not supported \\
& Administrator's comment & 0.087353 & $0.0223^{* *}$ & & Ha6.2 & Supported \\
& Constant & 0.186582 & 0.0000 & 0.478481 & & \\
& Hour & -0.128642 & $0.0009^{* * *}$ & & Ha1.3 & Supported \\
& Day & 0.186268 & $0.0000^{* * *}$ & & Ha2.3 & Supported \\
& Video & 0.550138 & $0.0000^{* * *}$ & & Ha3.3 & Supported \\
& Caption & 0.113129 & $0.0531^{*}$ & & Ha5.3 & Supported \\
& Administrator's comment & 0.047211 & 0.3150 & & Ha6.3 & Not supported \\
Constant & 0.007581 & 0.3807 & 0.960725 & & \\
& Hour & -0.011499 & 0.2437 & & Ha1.4 & Not supported \\
& Day & 0.020045 & $0.0369^{* *}$ & & Ha2.4 & Supported \\
& Video & 0.966445 & $0.0000^{* * *}$ & & Ha3.4 & Supported \\
& Caption & -0.015059 & 0.3121 & & Ha5.4 & Not supported \\
& Administrator's comment & 0.044137 & $0.0002^{* * *}$ & & Ha6.4 & Supported \\
\hline
\end{tabular}

$\mathrm{n}=442 ; * * *$ significant at $\mathrm{p}<0.001 ; * *$ significant at $\mathrm{p}<0.05 ; *$ significant at $\mathrm{p}<0.1$

Source: Primary data, 2018

F COMMENTS $=0.212-0.076 *$ HOUR +

$$
\begin{aligned}
& 0.182 * \text { DAY }+0.541 * \text { VIDEO }- \\
& 0.022 * \text { CAPTION }+ \\
& 0.0876 * \text { A_COMMENT }+\varepsilon
\end{aligned}
$$

Equation 3 shows that the day and administrators' comments have a positive effect on fans comments, but the hour has a negative effect. This means that increasing the number of videos posted or the administrators' comments helps the brand increase the number of fans comments; decreasing the number of day post will increase the number of fans comments. These findings are different from the previous study, where time (both the day and the hour) had a significant positive effect on fans comments, while video has no evidential effect and is only significant for image (Sabate et al.,2014); Swani \& Milne, 2017), but we have the same findings as Schultz (2017), that video has a significant effect on comments.

\section{Model of Shares}

The behavior of shares indicates that the users recommend the provided information to other users. There are several reasons why a user shares content, including to spread information, entertain, invite participation such as voting or surveys, or to express his/her opinion (agree or disagree), the reasons depend on the type of content. Shares of a brand's post are an efficient electronic word of mouth method to increase a 
brand's awareness and popularity, and to gain potential customers.

$$
\begin{gathered}
\text { SHARES }=0.187-0.129 * \text { HOUR }+ \\
0.186 * \text { DAY }+0.550 * \text { VIDEO }+ \\
0.113 * \text { CAPTION }+ \\
0.047 * \text { A_COMMENT }+\varepsilon
\end{gathered}
$$

As shown in Table 2, the shares model explains $48 \%\left(\mathrm{R}^{2}\right)$ of the shares variables with an adjusted R-square of 0.478481 . There is a significant negative effect between shares and the hour ( $\mathrm{p}$-value $<0.001 ; \beta=-0.129$ ) and a significant positive effect for the day ( $\mathrm{p}$-value $<$ $0.001 ; \beta=+0.186$ ), video ( $\mathrm{p}$-value $<0.001 ; \beta=$ +0.550 ) and caption ( $\mathrm{p}$-value $<0.1 ; \beta=+0.113$ ). A part of these findings is in line with Schultz (2017), who said that the number of shares is significantly affected by video. Equation 4 shows that to increase the number of shares; the number of videos should be increased, as should the number of captions or posts in a day. However, there is no significant effect between administrators' comments ( $\mathrm{p}$-value $=0.3150 ; \beta=$ +0.074 ) and the number of shares.

\section{Model of Views}

Table 2 and Equation 5 show significant and positive effects between views and the day (pvalue $<0.05 ; \beta=+0.020$ ), video ( $\mathrm{p}$-value $<$ $0.001 ; \beta=+0.966)$, and administrators' comments (p-value $<0.001 ; \beta=+0.0441$ ). It means that increasing the number of at least one of these variables, while the other variables remain constant, will increase the number of views. The resulting model explains that $96 \%$ of the views' variance, with the adjusted R-squared in this model, is 0.960725 (Table 2). The hour and caption have non-significant and negative effects on views.

$$
\begin{gathered}
\text { VIEWS }=0.008-0.0115 * \text { HOUR }+ \\
0.020 * \text { DAY }+0.966 * \text { VIDEO }-
\end{gathered}
$$

$$
\begin{aligned}
& 0.015 * \text { CAPTION }+ \\
& 0.0441 * \text { A_COMMENT }+\varepsilon
\end{aligned}
$$

\section{Post effectiveness on brand popularity}

There are three post effectiveness categories tested in this study, namely posts per day, the time of a post, and administrators' comments. As explained in the previous discussion, the day the post is made has a significant effect on the likes, fans comments, shares, and views models. The time of a post has a significant effects on fans comments and shares; while the administrators' comments have a significant effect on fans comments and views. The popularity of the brand in this test is measured by the average sum of the number of likes, shares, views, and fans comments.

The results of the Mann-Whitney and Kruskal-Wallis tests are shown in Table 3. For the hour, there is a significant difference between no post, non-busy hours, and busy hours on the brand's popularity ( $p$-value $>0.01$ ). By comparing the mean rank value, we see that a busy hours' post (269.71) is more significant than a non-busy hours' post (233.74) and no post (167.91). It means that the busy hour post is more useful than a non-busy hour one. These findings are in line with Brookes (2010), Buddy Media Inc. (2012) and Sabate et al. (2014), who all found that a busy hours' post is more effective than a post during the non-busy hours. The day the post is made shows a significant difference between no post, the weekend, and weekdays (p-value $<0.001$ ). Posts on weekdays (239.03) are more effective for increasing a brand's popularity than those made on weekends (236.46). This finding is in line with Brookes (2010) but contrary to Buddy Media Inc. (2012), Sabate et al. (2014), and Schultz (2017).

The administrators' comments shows significant different effects between no comment and one or more comments ( $\mathrm{p}$-value $<0.001$ ). By 
Table 3. Differences test results

\begin{tabular}{|c|c|c|c|c|}
\hline Variables & Categories & $\mathrm{N}$ & Mean Rank & Asym. Sig. (2-tailed) \\
\hline \multirow[t]{4}{*}{ Hour } & No post & 146 & 167.91 & \multirow{4}{*}{$0.000 * * *$} \\
\hline & Non-busy hour & 184 & 233.74 & \\
\hline & busy hour & 111 & 269.71 & \\
\hline & Total & 441 & & \\
\hline \multirow[t]{4}{*}{ Day } & No post & 105 & 168.39 & \multirow[t]{4}{*}{$0.000 * * *$} \\
\hline & Weekend & 129 & 236.46 & \\
\hline & Weekdays & 208 & 239.03 & \\
\hline & Total & 442 & & \\
\hline \multirow{3}{*}{$\begin{array}{l}\text { Administrators' } \\
\text { comments }\end{array}$} & No comment & 345 & 208.15 & \multirow{3}{*}{$0.000 * * *$} \\
\hline & One or more comments & 97 & 268.99 & \\
\hline & Total & 442 & & \\
\hline
\end{tabular}

comparing the mean rank, we see that administrators who give one or more comments are more effective at increasing a brand's popularity. It means that two-way communication between the brand and its fans is better for increasing the brand's popularity. These results indicate that the users prefer two-way communication between the brands and themselves. Naturally, humans feel more appreciated when their communications are responded to by others.

\section{DISCUSSION}

This paper is aimed at developing social media's branding research by exploring how brands manage their fan pages to increase their popularity. The results show a strong effect of videos on a brand's popularity, indicated by the number of likes, shares, comments, and views. It means that the ability of brands to provide attractive visual content is an excellent strategy for beating their competitors on social media. Other studies have found that the visual content of social media promotions has significant effects on the decision to purchase (Sharma et al., 2012; Hellberg, 2015); Hanifawati, Dewanti,\& Saputri, 2019).
The human brain is better at processing visual than verbal information (Sharma et al., 2012). This theory is in line with Brookes (2010) and Sabate et al. (2014), who state that images and videos are preferred by users rather than text messages. The advantage of video is it has the ability to display verbal and visual information that is more easily understood. According to Geurin \& Burch (2017), an attractive and highquality video receives more users' engagement. Red Bull, an energy drink brand, is, based on our observations, the most consistent in posting videos. Its posts always get thousands and even millions of views. Red Bull successfully established a strong emotional bond with its customers through extreme sports videos. Rambe \& Jafeta (2017) said that energy drinks are often associated with parties, music, and sports, which are all interpreted as the lifestyle of young people, who are their target market.

Another exciting thing is, except for displaying their logo in every video, there is rarely any invitation to drink Red Bull; people are rarely shown drinking their product in the videos. In other words, the focus of its branding is on building brand awareness through the 
displayed logo in each video. This is very different from other food and beverage brands, which generally displaying their products to invite people to consume them. Anthony Hearne, Outbrain's Regional Director for Southeast Asia, India \& New Markets, said that $82 \%$ of consumers prefer brand content that provides value rather than brand content that only advertizes itself. He also explained that content is the only way to win consumers in a branding competition in the digital era (Iriansyah, 2016). In line with Kotler \& Keller (2009), the main goals of brand management are creating, communicating, and transferring value to the target market, to generate profits.

The interesting question is then: "Which one is best between videos with captions or videos without captions?" Our findings show that captions have significant effects on likes and shares but not on comments and views. It is not surprising if captions do not affect the number of views, because the views feature is only for videos. In our assumption most users only focus on visual content that attracts their emotional interest, and then they start to comment, while captions do not need comments. The research found that social media users prefer visual content over verbal (Gulamali \& Persson, 2017; Hanifawati et al., 2019). There is a significant and positive correlation between the effects of visual content and captions on the purchasing decision (Hanifawati et al., 2019). This means that a caption strengthens the effects of the visual material (video, image). The number of text characters has a significant effect on likes (Sabate et al., 2014). Texts that contain less than 100 characters receive $17 \%$ higher engagement than longer texts (Buddy Media Inc., 2012), so Sabate et al., (2014) suggested that specific and detailed information is more liked by the users. Therefore, adding captions with less than 100 characters to posted videos or images with detailed information about the content is best for increasing the posts' popularity.

We surprisingly found that the day of the post had substantial effects on all forms of brand engagement, although weekdays were found to be more effective. These findings differ from those of previous studies. The assumption is because the brands in our study post almost every day, or there may be a correlation between the effectiveness of the date and day with the chosen industry category. Sabate et al. (2014) analyzed the travel industry and no found evidence of the day; Schultz (2017) studied the retail industry and also found no effects. Cvijikj \& Michahelles (2013) analyzed the food and beverage industry and found it was significant for comments, but not for likes. Also, we studied food/beverage brands and found it to be significant for all the models. Buddy Media Inc. (2012) reported that different industries have more engagement on different days, such as the sports industry has more engagement on a Saturday or Sunday, also the clothing and fashion industry, entertainment on Sundays and Mondays, and publishing on a Saturday. However, it still needs further research to prove our assumption. The time of the post has a significant effect on comments and shares but not on likes and views, where the busy hours are more significant than the non-busy hours. It indicates that in working hours the users may stay in front of a laptop/computer and be connected with social media for the purpose of their work, or not. At those times, they have more time to engage with social media and prefer to engage in comments and shares than views and likes.

The results also show that the administrators' comments show a significant effect on comments and views, but not on likes and shares, where users prefer to have an active interaction rather than a passive one. It is not surprising that 
administrators' comments have a greater effect on fans' comments, but it is surprisingly that they can increase the number of views. With the administrators' comments, the conversation becomes alive. The more people that comment on the post, the more curious other users are to watch the video. After viewing, they prefer to give comments rather than likes and shares. Sharing is only done if the information is considered essential for others to know.

Our observations show that Starbucks is the most interactive for establishing communications on their fan page. Starbuck's administrators have a great deal of interaction with the fans; they almost always reply to all types of comments, such as suggestions, complaints, or others. In almost every reply, the administrator greets the fans kindly, and uses their name, such as "Hi, Ray"; "Hi, there JD"; "Thanks for this kind word, John!" Starbuck's administrators also show thoughtful responses to those who submit negative feedback of their services. They also give real appreciation to customers who provide positive feedback or suggestions. An interesting finding we discussed here is that the replies of brand administrators have a significant and positive effect on fans comments and views. We have not found an explanation for this variable in previous studies. The question is, "What is the implication of this finding?" First, these findings help give ideas to managers, not only about how to increase their brand's popularity and provide two-way communication, but also how to build a deeper engagement with their customers and gain new ideas for their business's development from them, by maximizing the comments feature. In typical conditions, they must spend a lot of time and money to gain ideas through a survey of their customers. Second, these findings confirm the effectiveness of the comment feature in social media for inbound marketing; as with an inbound marketing strategy, a brand has excellent possibilities to have a greater connection, improved brand awareness, and gain more trust from its customers, although without them necessarily purchasing the item. More research is needed to gain more insight into these findings.

A firm might need a platform to gather ideas in the ideation stage, use toolkits to enhance the product's design in the development stage or rely on virtual product testing in the launch phase (Muninger et al., 2019). In this case, consumers help to create value by helping companies understand their needs, participating in a product's development, providing feedback on products or service and becoming product advocates (Sashi, 2012; Hausman, Kabadayi, \& Price, 2014). In business, customers are the main actors in the ideation and product development processes. Social media, such as Facebook, is highly interactive and meets those needs (of both the customers and company). Starbucks captured the opportunity very well and made their fan page a source of ideation and market research, to gather new ideas about their products and services, based on their customers' needs. They collect the data through an online form, so it can be accessed in real-time and is more easy to analyze. This finding reinforces Sashi's (2012) opinion that, "Interactions among sellers and their customers can improve the understanding of customers' needs, especially changes in these needs over time, and facilitate modifications to existing products or the development of new products to better satisfy these needs."

Finally, this study was found to support the majority of the proposed framework and hypotheses, as presented in Section 2, and it also filled the gap in the research, as explained in the introduction. We have some points that can be considered as robust findings - first, the power of visual content is the best competitive strategy. Engaging content (visual and verbal) is needed 
to build deep brand involvement. Content is the main attraction for users watching, liking, sharing, and commenting. Second, although the time of a post (the hour and day) is still being debated for its significance, we agree that managing the timing and consistency of a post is critical in building both popularity and proper engagement with the followers. Third, building active communications between the brand and its followers is very strongly recommended as a strategy to increase the brand's popularity, and also to enhance customer relations and loyalty.

\section{CONCLUSIONS, LIMITATIONS, AND SUGGESTIONS FOR FUTURE RESEARCH}

From this research, we conclude that social media is a useful tool for building the popularity of brands. The number of likes is significantly affected by the day, video, and caption while the time of a post and the administrators' comments have no significant effect. The number of fans comments is significantly affected by the hour and day a post is made, and if it has a video, while caption has no significant effects. The number of shares is significantly affected by the hour, day, video, and caption while administrators' comments are not significant. The number of views is significantly affected by the day, video, and administrators' comments, while the hour and caption have no significant effects. These variables explain $64.17 \%$ of the likes model, $54.53 \%$ of the fans comments model, $47.85 \%$ of the shares model, and $96.07 \%$ of the views model. Posting on a weekday during the busy hours is more useful for increasing a brand's popularity than a post on weekends at a non-busy time. Active brand communication is more useful for increasing a brand's popularity than passive brand communication.

The study's findings have three important implications for managers. First, it is better to provide active communications. Brand adminis- trators should be chosen explicitly for their excellent communication skills, and should be friendly and caring towards the customers. Marketing innovations through social media not only help brands to build a strong relationship with the customers, but also gain new ideas for product and service developments. Second, to beat the competing brands on social media, a company should have the ability to present an engaging and emotional visual content, especially via video. Adding captions to video posts will increase the popularity of the posts. Third, managing the timing of a post is essential, it is recommended that posts should be made on weekdays during the busy hours; posts should be made on most days of the week, to increase the brand's popularity. We suggest posting consistently and continuously at such times.

Even though our study makes a contribution, it still has its limitations. First, the research objective of effectiveness is too general. The research objectives for further research need to be narrowed to increase the research's focus. For example, focus on the most effective kinds of content, the types of brand communications, date and day (such as Sunday or Monday), and the peak times (such as 10:00-11:00 or 15:0016:00). In our assumption, these findings will be of significant benefit when the kinds of effectiveness are analyzed in detail. Second, the data's collection was only through fan page activity. There is the possibility of fake accounts or paid accounts used to enliven the fan page so the data may be biased. In our assumption, a direct survey sent to the followers of the brand about these variables will produce more accurate findings. Also, in the case of top international brands, it would be exciting to provide a different response from the audience in a different context, e.g., different countries or other characteristics of their engagement with 
the brand. Enhancing these limitations will open the opportunities for future research.

\section{Acknowledgment}

We want to thank to Directorate of Research and Service for Society of the Indonesian Ministry of Research, Technology and Higher Education for providing us with a grant for this research.

\section{REFERENCE}

Beasley, T. M. (2008). Seemingly unrelated regression (SUR) models as a solution to path analytic models with correlated errors. Multiple Linear Regression Viewpoints, 34(1), 1-7. Retrieved from https://www.soph.uab.edu/bsttenure/beasley /Beasley-SUR-MLRV-2008.pdf

Brookes, E. J. (2010). The Anatomy of a Facebook Post Study on Post Performance by Type, Day of Week, and Time of Day. Retrieved from

https://marketingavatar.files.wordpress.com/ 2010/11/the-anatomy-of-a-facebookpost.pdf

Buddy Media Inc. (2012). Strategies for Effective Tweeting: A Statistical Review Introduction 3. Retrieved from www.buddymedia.com

Coursaris, C. K., Van Osch, W., \& Balogh, B. A. (2016). Do Facebook likes lead to shares or sales? Exploring the empirical links between social media content, brand equity, purchase intention, and engagement. Proceedings of the 49th Annual Hawaii International Conference on System Sciences, 2016-March(January), 35463555.

https://doi.org/10.1109/HICSS.2016.444

Cvijikj, I. P., \& Michahelles, F. (2013). Online engagement factors on Facebook brand pages. Social Network Analysis and Mining, 3(4), 843-861. https://doi.org/10.1007/s13278-013-0098-8

Erdoğmuş, İ. E., \& Çiçek, M. (2012). The impact of social media marketing on brand loyalty. Procedia - Social and Behavioral Sciences, 58, 1353-1360.

https://doi.org/10.1016/J.SBSPRO.2012.09. 1119

Fitrianti, R. (2018). Estimasi Model Seemingly Unrelated Regression (SUR) Pada Foreign Direct Investment (FDI) di Indonesia, Singapura, dan Filipina. Yogyakarta. Retrieved from

https://dspace.uii.ac.id/bitstream/handle/123 456789/5457/14611094_RIFA

FITRIANTI.pdf?sequence $=1$

Geurin, A. N., \& Burch, L. M. (2017). Usergenerated branding via social media : An examination of six running brands. Sport Management Review, 20(3), 273-284. https://doi.org/10.1016/j.smr.2016.09.001

Greene, W. H. (2002). Econometrics Analysis (5th ed.). New Jersey: Prentice-Hall. Retrieved from

https://spu.fem.uniag.sk/cvicenia/ksov/obtul ovic/Manaž. štatistika a ekonometria/EconometricsGREENE.pdf

Gulamali, A., \& Persson, J. (2017). The Social Media Influencer and Brand Switching. Lund University. Retrieved from http://lup.lub.lu.se/luur/download?func $=$ do wnloadFile\&recordOId $=8910352 \&$ fileOId $=$ 8910354

Hanifawati, T., Dewanti, V. W., \& Saputri, G. D. (2019). Motivasi dan peran sosial media influencer terhadap brand switching produk makanan-minuman pada generasi y dan $z$. Laporan Penelitian. Universitas Muhammadiyah Bandung, Bandung.

Hanifawati, T., Suryantini, A., \& Mulyo, J. H. (2017). Pengaruh atribut kemasan makanan dan karakteristik konsumen terhadap pembelian. Agriekonomika, 6(9), 73-86. https://doi.org/http://dx.doi.org/10.21107/ag riekonomika.v6i1.1895

Hausman, A., Kabadayi, S., \& Price, K. (2014). Consumer-brand engagement on Facebook: Liking and commenting behaviors. Journal of Research in Interactive Marketing, 8, 169-202. https://doi.org/10.1108/JRIM-122013-0081 
Hellberg, M. (2015). Visual Brand Communication on Instagram: A study on consumer engagement. Hanken School of Economics. Retrieved from

https://helda.helsinki.fi/bitstream/handle/10 138/156026/hellberg.pdf?sequence $=4$

Henningsen, A., \& Hamann, J. D. (2007). System fit: a package for estimating systems of simultaneous equations in r. Journal of Statistical Software, 23(4), 1-40.

https://doi.org/10.18637/jss.v023.i04

Hudson, S., Huang, L., Roth, M. S., \& Madden, T. J. (2016). The influence of social media interactions on consumer-brand relationships: a three-country study of brand perceptions and marketing behaviors. International Journal of Research in Marketing, 33(1), 27-41.

https://doi.org/10.1016/j.ijresmar.2015.06.0 04

Iriansyah, F. Y. (2016). Anthony Hearne: Content Marketing, dari Hati Turun ke Kepala. Retrieved October 31, 2018, from https://id.techinasia.com/outbrain-contentmarketing

Jothi, P. S., Neelamalar, M., \& Prasad, R. S. (2011). Analysis of social networking sites: A study on effective communication strategy in developing brand communication. Journal of Media and Communication Studies, 3(7), 234-242. Retrieved from http://www.academicjournals.org/article/arti cle1380266912_Jothi et al.pdf

Kallio, K. (2015). The Effectiveness of Social Media as a Marketing Communication Tactic, Case Gina Tricot Ltd. Vaasan Ammattikorkeakoulu University of Applied Sciences. Retrieved from

https://www.theseus.fi/bitstream/handle/100 24/98146/Kallio_Kira.pdf?sequence=1\&isA llowed $=\mathrm{y}$

Kaur, W., Balakrishnan, V., Rana, O., \& Sinniah, A. (2019). Liking, sharing, commenting and reacting on Facebook: User behaviors' impact on sentiment intensity. Telematics and Informatics, 39,
25-36.

https://doi.org/10.1016/j.tele.2018.12.005

Kim, A. J., \& Johnson, K. K. (2016). Power of consumers using social media: Examining the influences of brand-related usergenerated content on Facebook. Computers in Human Behavior, 58, 98-108. https://doi.org/10.1016/j.chb.2015.12.047

Kim, C., \& Yang, S. U. (2017). Like, comment, and share on Facebook: how each behavior differs from the other. Public Relations Review, 43(2), 441-449.

https://doi.org/10.1016/j.pubrev.2017.02.00 6

Kim, J. H. (2018). Effect of brand popularity as an advertising cue on tourists' shopping behavior. Journal of Destination Marketing \& Management, 10, 78-86.

https://doi.org/10.1016/j.jdmm.2018.07.001

Kotler, P., \& Keller, K. L. (2009). Manajemen Pemasaran edisi 12 Jilid 1. Jakarta Barat: PT Indeks.

Kudeshia, C., \& Kumar, A. (2017). Social eWOM: Does it affect the brand attitude and purchase intention of brands? Management Research Review, 40(3), 310-330. https://doi.org/10.1108/MRR-07-2015-0161

Kuncoro, M. (2013). Metode Riset untuk Bisnis dan Ekonomi Bagaimana Meneliti dan Menulis Tesis (4th ed.). Jakarta: Erlangga.

Lin, H. C., Swarna, H., \& Bruning, P. F. (2017). Taking a global view on brand post popularity: Six social media brand post practices for global markets. Business Horizons, 60(5), 621-633.

https://doi.org/10.1016/j.bushor.2017.05.006

Magnini, V. P., Karande, K., Singal, M., \& Kim, D. (2013). The effect of brand popularity statements on consumers, purchase intentions: The role of instrumental attitudes toward the act. International Journal of Hospitality Management, 34, 160-168. https://doi.org/10.1016/j.ijhm.2013.02.010

Mansuri. (2016). Modul Praktikum Eviews 9. Jakarta: Fakultas Ekonomi Universitas Borobudur. 
Mohajan, H. K. (2017). Two criteria for good measurements in research: Validity and reliability. Annals of Spiru Haret University. Economic Series, 17(4), 59-82. Retrieved from https://mpra.ub.uni-muenchen.de/ 83458/1/MPRA_paper_83458.pdf

Muninger, M. I., Hammedi, W., \& Mahr, D. (2019). The value of social media for innovation: A capability perspective. Journal of Business Research, 95(July 2017), 116-127.

https://doi.org/10.1016/j.jbusres.2018.10.012

Piller, F.T., Vossen, A., \& Ihl, C. (2012). From social media to social product development: The impact of social media on co-creation of innovation. Die Unternehmung, 66(1), 727. https://doi.org/10.5771/0042-059X2012-1-7

Rambe, P., \& Jafeta, R. J. (2017). Impact of social media advertising on high energy drink preferences and consumption. Journal of Applied Business Research (JABR), 33(4), 653-668. https://doi.org/10.19030/jabr.v33i4.9977

Roberts, D. L., \& Candi, M. (2014). Leveraging social network sites in new product development: Opportunity or hype? Journal of Product Innovation Management, 31, 105-117. https://doi.org/10.1111/jpim.12195

Sabate, F., Berbegal-Mirabent, J., Cañabate, A., \& Lebherz, P. R. (2014). Factors influencing popularity of branded content in Facebook fan pages. European Management Journal, 32(6), 1001-1011.

https://doi.org/10.1016/j.emj.2014.05.001

Saboo, A. R., Kumar, V., \& Ramani, G. (2016). Evaluating the impact of social media activities on human brand sales. International Journal of Research in Marketing, 33(3), 524-541. https://doi.org/10.1016/ j.ijresmar.2015.02.007

Sashi, C. M. (2012). Customer engagement, buyer-seller relationships, and social media. Management Decision, 50(2), 253-272. https://doi.org/10.1108/00251741211203551

Schnotz, W. (2005). An Integrated Model of Text and Picture Comprehension. In R.
Mayer (Ed.), The Cambridge Handbook of Multimedia Learning (pp. 49-70). Cambridge: Cambridge University Press. https://doi.org/10.1017/CBO978051181681 9.005

Schultz, C. D. (2017). Proposing to your fans : Which brand post characteristics drive consumer engagement activities on social media brand pages? Electronic Commerce Research and Applications, 26, 23-34. https://doi.org/10.1016/j.elerap.2017.09.005

Sharma, A., Bhosle, A., \& Chaudhary, B. (2012). Consumer perception and attitude towards the visual elements in social campaign advertisement. IOSR Journal of Business and Management (IOSRJBM), 3(5), 6-17. Retrieved from www.iosrjournals.org

Smieško, I. (2016). Criminal liability of Facebook reaction buttons in environment of the Slovak Republic as a Form of hate speech. Societas Et Iurisprudentia, 4, 213234. Retrieved from http://sei.iuridica.truni.sk

Statcounter. (2019). Social media stats Indonesia - March 2019. Retrieved April 21, 2019, from http:/gs.statcounter.com/social-mediastats/all/indonesia/\#monthly-201901201903-bar

Statista. (2018). Number of mobile social network users in Indonesia from 2013-2018. Retrieved December 21, 2018, from https://www.statista.com/statistics/415841/n umber-of-mobile-social-network-users-inindonesia/

Su, N., Reynolds, D., \& Sun, B. (2015). How to make your Facebook posts attractive: a case study of a leading budget hotel brand fan page. International Journal of Contemporary Hospitality Management, 27(8), 32. https://doi.org/10.1108/IJCHM-06-20140302

Swani, K., \& Milne, G. R. (2017). Evaluating Facebook brand content popularity for service versus goods off erings. Journal of Business Research, 79, 123-133. https://doi.org/10.1016/j.jbusres.2017.06.003 
Swani, K., Milne, G. R., Brown, B. P., Assaf, A. G., \& Donthu, N. (2017). What messages to post? Evaluating the popularity of social media communications in business versus consumer markets. Industrial Marketing Management, 62, 77-87. https://doi.org/ 10.1016/j.indmarman.2016.07.006

Taherdoost, H. (2016). Validity and reliability of the research instrument; How to test the validation of a questionnaire/survey in a research. SSRN Electronic Journal, (January 2016). https://doi.org/10.2139/ssrn.3205040

Verhoef, P. C., \& Lemon, K. N. (2013). Successful customer value management: Key lessons and emerging trends. European Management Journal, 31(1), 1-15. https://doi.org/10.1016/J.EMJ.2012.08.001

Vukasovič, T. (2013). Brand developing relationships through social media. In Management, Knowledge and Learning International Conference (pp. 19-21). Croatia. Retrieved from https://pdfs.semanticscholar.org/014f/0793c 15b817dcdbe321cf0c62a9b5f67e366.pdf

Vukasović, T., \& Strašek, R. (2014). A Study on Effective Communication Strategy in Developing Brand Communication: Analysis of Social Networking Site. A Study on Effective Communication Strategy in Developing Brand Communication, 1 (September), 3-6. Retrieved from http://www.iaeng.org/publication/WCE2014 /WCE2014_pp690-693.pdf

Wang, W. Y., Pauleen, D. J., \& Zhang, T. (2016). How social media applications affect B2B communication and improve business performance in SMEs. Industrial Marketing Management, 54, 4-14.

https://doi.org/10.1016/j.indmarman.2015.1 2.004

We Are Social. (2019). Global Digital Report 2019. Retrieved from

https://wearesocial.com/uk/digital-2019

Widarjono, A. (2010). Analisis Statistika Multivariat Terapan. Yogyakarta: UPP STIM YKPN.

Widyaningsih, A., Susilawati, M., \& Sumarjaya, I. W. (2014). Estimasi Model Seemingly Unrelated Regression (SUR) dengan Metode Generalized Least Square (GLS). Jurnal Matematika, 4(2), 102-110.

Zadeh, A. H., \& Sharda, R. (2014). Modeling brand post popularity dynamics in online social networks. Decision Support Systems, $65,59-68$.

https://doi.org/10.1016/j.dss.2014.05.003 


\section{Appendix}

Table 4. Observation form template

\begin{tabular}{|c|c|c|c|c|c|c|c|c|c|c|c|}
\hline \multicolumn{12}{|c|}{ OBSERVATION FORM } \\
\hline \multicolumn{12}{|c|}{ Name of Brand } \\
\hline \multicolumn{12}{|c|}{ Name of Observer } \\
\hline \multirow{3}{*}{ Date } & \multicolumn{11}{|c|}{ Variable of Research } \\
\hline & \multicolumn{2}{|c|}{ A.Post Time } & \multicolumn{3}{|c|}{ B.Post Content } & C.Brand Communication & \multicolumn{4}{|c|}{ D.Brand Popularity } & \multirow{2}{*}{\begin{tabular}{|c|}
$\begin{array}{c}\text { E.Followers } \\
\text { Number }\end{array}$ \\
\end{tabular}} \\
\hline & Hour & Day & Video & Image & Caption & Admin Comment & Likes & Fans Comment & Shares & Views & \\
\hline & & & & & & & & & & & \\
\hline & & & & & & & & & & & \\
\hline & & & & & & & & & & & \\
\hline & & & & & & & & & & & \\
\hline & & & & & & & & & & & \\
\hline & & & & & & & & & & & \\
\hline & & & & & & & & & & & \\
\hline & & & & & & & & & & & \\
\hline & & & & & & & & & & & \\
\hline & & & & & & & & & & & \\
\hline & & & & & & & & & & & \\
\hline & & & & & & & & & & & \\
\hline & & & & & & & & & & & \\
\hline & & & & & & & & & & & \\
\hline & & & & & & & & & & & \\
\hline & & & & & & & & & & & \\
\hline & & & & & & & & & & & \\
\hline & & & & & & & & & & & \\
\hline & & & & & & & & & & & \\
\hline & & & & & & & & & & & \\
\hline & & & & & & & & & & & \\
\hline & & & & & & & & & & & \\
\hline & & & & & & & & & & & \\
\hline & & & & & & & & & & & \\
\hline & & & & & & & & & & & \\
\hline & & & & & & & & & & & \\
\hline & & & & & & & & & & & \\
\hline & & & & & & & & & & & \\
\hline & & & & & & & & & & & \\
\hline & & & & & & & & & & & \\
\hline
\end{tabular}

